\title{
TOPLAM KALITE YÖNETIMINDE LIDERLIK : LIDERLIKTE KALITE
}

\author{
AHMET YATKIN
}

Yrd.Doç.Dr, Fırat Üniversitesi, İletişim Fakültesi

\section{ÖZET}

Liderlik, işletmeler için önemli bir yönetimsel araç konumundadır. Liderliğin pek çok tanımı mevcuttur. Ancak en kısa tanımıyla liderlik, insanları etkileyebilme gücüdür. Daha genel anlamda liderlik, insanları işlerini daha iyi yapabilmeleri doğrultusunda yönlendirebilme, motive edebilme ve örgütün amaçlarına ulaşmasını kolaylaştıracak ortamlar yaratabilme yeteneği ve becerisidir. Insan kaynağı ve kurumsal hedefler örgütsel amaca ulaşmada iki önemli unsurdur.

Bu çalışmada modern yönetim sistemlerinden birisi olan toplam kalite yaklaşımı ve kalite geliştirme çabalarının önemli bir parçası olan liderlik, liderlikte kalite ve kalitede liderlik kavramlarına vurgu yapılarak incelenecektir.

Anahtar Sözcükler: Toplam Kalite Yönetimi, Liderlik, Motivasyon, Katılım, vizyon.

\section{ABSTRACT}

Leadership is an important managerial tool for business organisations. There are many definitions of leadership. One of the short definition is; Leadership is the power of influencing people. In more general meaning, leadership is the skills and abbilities to help people do a better job through 
coaching, facilitating, and by creating environments that support the aim of organization. Human resources and institutional targets are two important subjects to reach organizational objectives.

In this study we will examine the total quality approach which is one of the modern managing system and leadership as an essential part of a quality improvement effort, quality of leadership and leadership in quality will be mainly discussed.

Key Words: Total Quality Management, Leadership, Motivation, Participation, Vision.

\section{GíRiş}

Bilindiği gibi insan, ilişkileri içinde varolabilen sosyal bir varlık olarak tanımlanmaktadır. İnsanın günlük yaşamının önemli bir bölümü diğer kişi ve gruplar içindeki ilişkileriyle geçmektedir. Kurulan ilişkilerde gerekli olan bilgi, düşünce, duygu alış-verişiyle olumlu bir davranış ve tutum geliştirme, karşılıklı beklentileri paylaşma ve bu beklentilerin birbirini tamamlaması yönünde önemli sayılabilecek çaba göstermektedirler. İnsan yaşamının, örgütlü toplumsal düzenin vazgeçilmez aracı olan liderlik, bilimsel ve güncel tartışmaların temel konusu haline gelmiştir. Aynı şekilde insan gibi etkileşim ve karşılıklı ilişki içinde olan kurumlar veya kuruluşlar açısından da başarı, etkililik ve kalitenin gizi liderliktir.

Liderlik konusunun, bilgi çağı diye adlandırdığımız günümüzde sosyal-beşeri bilimlerin odağı haline gelmesi, teknolojik gelişme ve ilerlemeler yanında sosyal, ekonomik, siyasal gelişmelerle de yakında ilgilidir. Sanayileşme sürecinde artan üretim, dağıtım ve çeşitlenen tüketim, toplumsal ve siyasal yaşamdaki bütünleşme, son yıllarda bilgi sektörünün doğuşuyla birlikte bilgiye sahip olmanın kazandırdığı üstünlük, liderliğin önemini yönetim ve örgüt açısından daha da belirginleştirmiştir. 


\section{Liderliğin Tanımı ve Niteliği}

Liderlik, son yüzyıla damgasını vuran, önemli bir kavramdır. Bu kavram ile ilgili bir çok akademik çalışma yapılmış ve hala da yapılmaktadır. Bu nedenle liderlik ile ilgili bir çok farklı tanımlama ve yaklaşım bulunmaktadır. Ancak çok sayıdaki farklı tanımlama ve yaklaşıma rağmen, bunlar arasında bazı ortak noktalar bulunduğu ifade edilmektedir.

Liderlik, bireylerin ortaklaşa yaratılan vizyona dönük olarak bir araya gelmesini, istekli ve coşkulu olarak ortak hedefleri benimsemesini ve bu hedeflerin gerçekleşebilmesi için güçlenerek bütün varlıkları ile katkıda bulunmasını sağlayan enerjik bir süreç olarak açıklanabilir (www.spk-mpd.org, 22.12. 2005).

Lider, insanlara değer veren, onları dinleyen, onların sorun ve beklentileriyle ilgilenen, aynı zamanda sorunlara çözüm üretebilecek kapasitede olduğunu gösteren kişidir. Bir iletişim ustası olan liderin, insanlarla ilişkilerinde kullandığı ana yöntem "empati" yani kendisini başkalarının yerine koyarak düşünebilme becerisidir.

Lider, etkileyici bir vizyon sahibidir. Vizyonu, gelecekte elde edilmesi imkansız olmayan, buna karşılık kolaylıkla da elde edilemeyen ortak ve cazip bir hedeften oluşur.

Vizyon, kararlara yön gösterebilecek kadar hedefe odaklı, diğer yandan inisiyatif kullanmayı teşvik edecek kadar esnek olmalıdır (www.ba.metu.edu.tr, 22.12. 2005 ).

Liderlik (önderlik), temel beşeri, toplumsal ve evrensel olgulardan biridir. İnsanların grup, örgüt, topluluk olarak birlikte yaşadıkları ve faaliyet gösterdikleri tüm zamanlarda ve yerlerde liderlik söz konusudur. Ayrıca, liderliğin önemli olduğu konusunda adeta bir fikir birliği vardır. Ekonomik, siyasi, askeri başarılar ve başarısızlıklar, büyük ölçüde liderliğe atfedilmiştir. Bu nedenle, çokça konuşulan, yazılan, araştırılan ve farklı şekillerde tanımlanan bir olgudur. Nitekim, 1949'a kadarki liderlikle ilgili literatürü inceleyen V.J.Bentz, 130 farklı liderlik tanımı çıkarmışıı. Sonraki yıllarda ve farklı kültürlerde de liderliğin yoğun şekilde incelendiği göz önüne alınırsa, bu tanımların 
daha da çok olduğu söylenebilir. Ancak, önemli olduğu kabul edilmiş ve üzerinde çokça durulmuş olmasına rağmen, liderlik hala kesin olarak açıklanmış ve tanımlanmış bir kavram olmaktan uzaktır. Bu yüzden, üzerinde ittifak edilmiş tek bir önderlik tanımı da yoktur (www.merih.net, 24.12. 2005 ).

Liderlik, yalnızca "doğuştan sahip olanların" kabul edildiği bir kulüp değildir. Liderlerin sahip olması gereken özellikler vardır. Eğer bir kişi bu özelliklere istekle sahip olmaya çalışırsa onun lider olamaması için hiç bir neden yoktur.

Liderlik yaratıır, keşfedilmez. Doğaldır ki "doğuştan liderler" daima olacaktır ama, zirvede kalmak için doğal liderler dahi, liderlik özelliklerini geliştirmelidir. Lider olmak isteyen binlerce insan arasında yapılan incelemeler, hepsinin dört liderlik kategorisinden ya da seviyesinden birine uyduğunu göstermiştir:

Lider olarak doğanlar, liderlik nitelikleriyle doğup, hayatı boyunca liderlik örnekleriyle karşılaşmış, eğitim ile bu özelliklerini geliştirmiş, büyük bir lider olmak için kişisel disipline sahip olanlar,

Lider olmayı öğrenenler, hayatının büyük bölümünde liderlik örneğiyle karşılaşmış, eğitim sayesinde liderliği öğrenmiş, büyük bir lider olmak için kişisel disipline sahip olanlar, İçinde gizli liderlik bulunanlar, yakın geçmişte liderlik örnekleriyle karşılaşmış, eğitim sayesinde liderliği öğrenmiş, büyük bir lider olmak için kişisel disipline sahip olanlar,

Sınırlı liderliğe sahip olanlar, çok az liderlik örneği görmüş ya da hiç görmemiş, çok az liderlik eğitimi almış ya da hiç almamış, bir lider olabilmeyi isteyenler (Maxwell, 1998: 26).

Lider, liderlik yapan, izleyenlerin kendisini idare etme yetkisi verdikleri kişidir. Lider olma sürecine ilişkin olarak literatürde çok farklı yaklaşımlar bulunmaktadır. Lider, kendisini izleyenleri belirli bir amaç doğrultusunda hareket etmeye sevk eder. Liderlik karşılıklı etkileşimin var olduğu sosyal bir süreçtir. Bu süreç esnasında bir çok faktör (lider, izleyenler, durum) karşılıklı etkileşim içerisindedir. Diğer bir ifade ile liderlik süreci lider, izleyiciler ve durum arasındaki ilişkilerden oluşan karmaşık bir süreçtir.

Liderlik güç ve aklın birleşimidir. Akıl olmazsa güç zalimcedir. Güç olmazsa akıl manasızdır, boştur. Erk ya da güç, diğer kişilerin davranışlarını etkilemede bireyin yeteneği demektir. "Güç" ve "yetki" 
kavramlarının birbiriyle karıştırılmaması gerekir. Yetki, bir makamda bulunmaktan dolayı verilmiş olanak ve ayrıcalıkları belirtir. Güç ise; kişinin kendinden doğar. Kişinin gücü, ancak başkaları ile ilişkiye geçtiği andan itibaren ortaya çıkmakta; güç kullanmadaki başarısı bu süreçte karşısındakini ne kadar etkilediğine bağlı olmaktadır (www.spkmpd.org, 25. 12. 2005).

Etkileşimci bakış açısıyla, bir sosyal birim veya grup içinde tüm üyeler birbirleriyle etkileşim (etkileme ve etkilenme) içindedir. Buna göre, üyeler arası iletişim ve etkileşim iki yönlüdür. Bu süreçte lider ve diğer üyeler, hem etkiler hem de etkilenir. Bu durum en otoriter sistemlerde bile geçerlidir.Yalnız, önder ile diğer üyeler arasında etkileme gücü bakımından farklılıklar vardır. "Etkilemesi" daha yüksek olanlar lider; "etkilenmesi" daha yüksek olanlar ise "izleyici" olarak ortaya çıkacaklardır.

Liderle izleyiciler arasındaki etkileşimin genellikle sanıldığının aksine, iki yönlü olması, "liderin kim olacağı" yanında "liderin nasıl davranacağını" (hangi önderlik tarzını benimseyeceğini) de belirlemektedir. G.B.Grean'e göre liderin davranış tarzı, izleyicilerin performansını, izleyicilerin performansının yüksek veya düşük olması da önderin "hangi davranış tarzını benimseyeceğini" tayin etmektedir. Böylece lider, eğer astın performansı düşükse göreve yönelik yapıyı harekete geçirici, yüksekse insana ve ilişkilere önem veren bir önderlik tarzını benimseme eğiliminde olacaktır ( Grean, 1976 : 4).

İlgili tanımlara bakıldığında liderlik, ya bir süreç (önder ile üyeler arasındaki bir etkileme) ya da önderlik rol ve işlevlerini yerine getiren kişilerin sahip olduğu bir özellik olarak tanımlanmaktadır. Süreç olarak liderlik, grup üyelerinin amacın gerçekleştirilmesi doğrultusunda faaliyetlerinin (davranışlarının) yönlendirilmesi ve koordine edilmesi için zorlayıcı olmayan (noncoercive) etkinin kullanımıdır. Benzer bir tanımlamaya göre, önderlik, bir grup insanı belirli amaçlar etrafında toplayabilme ve bu amaçları gerçekleştirmek için onları harekete geçirme bilgi ve yeteneklerinin toplamı olarak tanımlanmıştır .

Bazı tanımlamalarda etkilemenin, yani astların davranışlarını amaç doğrultusunda değiştirmenin hangi güç kaynaklarının kullanımıyla, nasıl gerçekleştirildiği üzerinde pek fazla durulmamıştır. Ancak bazı yazarlar, örneğin Griffin ve Moorhead, liderliğin "zorlayıcı güç kullanımını içermediğini” ileri sürerler ( Brengelman, 1995: 41). Bu görüşe göre, sadece biçimsel otoritesine dayalı olarak insanları 
etkileyen bir yönetici, liderlik yapmamaktadır. Bu, liderliğin az veya çok liderlik özelliklerine sahip olma ve önder-izleyici ilişkilerinin zorlamaya değil, gönüllülük esasına dayalı olması, dolayısıyla her yöneticinin önder olmadığı yönündeki bir anlayışı yansıtmaktadır. Ancak, bu noktada yöneticilikle önderliğin tamamen ayrı olduğu ve ortak yönlerinin bulunmadığı gibi bir sonuç da çıkarılmamalıdır. Güç kaynakları farklı olsa da, yöneticiliğin de insanların davranışını ortak amaçlar doğrultusunda etkilemeyi/değiştirmeyi içerdiği, bu bakımdan önderlikle ortak bir paydasının olduğu unutulmamalıdır.

$\mathrm{Bu}$ açıklamalardan sonra, liderlik, belirli amaçların gerçekleştirilmesi yönünde insanların etkilenmesi, davranışlarının değiştirilmesi süreci olarak tanımlanabilir. Lider ise, bu etkileme işlevini yerine getiren kişi ya da kişilerdir denebilir. Önderlik, sadece biçimsel örgütlere ve yöneticilere özgü olmadığı gibi, sadece olağanüstü özellik ve yetkilerle donatılmış kişilere de mahsus değildir (www.merih.net, 25. 12.2005).

Örgütler liderlere intiyaç duyarlar. Bu ihtiyaç çeşitli nedenlerden ortaya çıkar:

1. Örgütün mevcut planları, ortaya çıkabilecek beklenmedik gelişmelere cevap veremeyebilir.

2. Örgütsel yapı değişen çevre koşullarına zamanla cevap veremeyebilir.

3. Örgütün büyüme dinamiği, yeni istemler ortaya çıkarabilir.

4. Örgütü oluşturan bireylerin, önceden tahmin edilemeyecek çeşitli tür davranışlarının varlığı ve bunlarla uğraşılmasıdır.

Genel olarak liderlik tanımlarının

a) amaçların gerçekleştirilmesi,

b) çok yönlü etkileşimlerin varlığı,

c) lidere atfedilen bir kısım özellikler gibi bazı ortak noktalar içerdiği söylenebilir. Farklı liderlik tanımlarından, liderlik ile ilgili şu ortak yargılara varılabilir: (www.spk-mpd.org, 25. 12. 2005).

1-Liderlik ve yöneticilik birbirinden farklıdır.

2-Liderlik, formal konuma bağlı değildir.

3-Liderlik, politiktir.

4-Liderlik, kültüreldir.

5-Liderlik, tinsel bazı özelliklerin ön plana çıktığı bir süreçtir. 
Lider, hedefe ulaşma sürecinde insanların içinde tutsak kalmış enerjiyi bulunduğu yerden çıkarıp ateşler. Hedef gerçekleştiği anda ise, başarıyı diğerlerine mal ederken, başarısızlığı kendi üzerine alır. Sonuca ulaşma sürecinde her türlü anlaşmazlığı basite indirger. Detaylarla fazla zaman harcamaz. Resmin tamamını görür.

Lider için değişim, yaşamın ta kendisidir. $O$, değişim için lider olur. Statüko, sürekli uzlaşma ve sonuçta yozlaşmayı yansıtır. Lider daima değişimle ilgilenir.

\section{Yöneticilik ve Liderlik Arasındaki Farklar}

Yönetmek, organizasyonun program ve konularının tam olarak işlediğinden emin olmak demektir. Oysa liderliğin, vizyon belirleme ve insanları motive etmekle doğrudan ilgisi vardır. İnsanlar yönetilmek değil yönlendirilmek isterler. Eğer birini yönetmek isterseniz, kendinizi yönetin. Bunun yolu da bunu iyi yaparak yönetmeyi bırakmak ve liderlik yapmaya hazırlanmaktan geçmektedir. İşin nasıl yapılacağını bilmek uzmanın, başkalarına nasıl yapacaklarını göstermek öğretmenin, başkalarının başardığından emin olmak yöneticilerin, başkalarını daha iyi çalışmak için esinlendirmek" ise liderin başarısıdır (Maxwell, 1998: 27).

Yöneticilik, değişimle ilgili olan liderlikten farklıdır. Yöneticiler, kurum ve kuruluşları yöneten ve varolan düzenin kurallarını devam ettirmek için çalışan, kısacası "status quo"yu koruyan kişilerdir ( www.ba.metu.edu.tr, 25. 12. 2005).

Yöneticilik bir meslektir ve işletmelerin kurulmasıyla ortaya çıkmıştır. Liderlik bir davranış biçimidir. Belli bir amaç doğrultusunda bir araya gelen insanların var olduğu her ortamda liderlikten söz edilebilir.

Örgütlerde yöneticilik daha çok örgütü temsil etme, grup gayretini koordine etme ve amaçlar doğrultusunda personeli yöneltme eylemi ve işlevidir. Örgütsel ve yönetimsel liderlik yöneticinin aynı zamanda doğuştan gelen liderlik gücü ve yeteneği ile astlarını etkili ve verimli bir şekilde çalıştırabilme, onları gönül gücüyle etkileyebilme yeteneğidir. Liderlik, en kısa tanımıyla insanları etkileme sanatıdır. Günümüzde her yönetici başarılı olabilmek için liderlik özelliklerine sahip olmalıdır. Günümüzde lider tek adam değildir. Ekibi olan bir takım oyuncusudur. Lider insan odaklı, katılımcı, paylaşımcı, yaratıcı, yalın, 
açık, esnek ve öncü kişidir. Misyon ve vizyon sahibidir. Dolayısıyla örnek kişidir.

Her yönetici liderlik özelliklerini taşımayabilir. Yani, her yönetici bir lider değildir. Ancak son yıllarda işletmeler, "lider yönetici” özelliğine sahip kişileri bünyelerinde görmek istemektedirler. Yönetici hak ve yetki sahibidir ancak, güç ve yetenek liderde varolan özelliktir (www.la21turkey.net, 25. 12. 2006).

İşletmeler en yetenekli insanları yönetici olarak seçerler. Ancak belirsiz ortamlar, değişime duyulan gereksinim yönetimde liderlik yaklaşımını gerekli hale getirmektedir. Yetkilerle donatılmış gücün yerine, bütün bir ekiple beraber kollektif hareket ederek, daha iyiye taşıma ve sıçrama yaşanabilir. Yakın geçmişte işletmelerin ana sorunları üretimin devamlılığı, rekabetten korunma ya da dağıtım sistemlerinin mükemmelleştirilmesi iken artık bu tür sorunları zaten her işletmenin çözmüş olması gerekirken, asıl fark hizmet ve deneyimle yakalanabiliyor. Başarı, yöntemlerin ve reçetelerin delege edildiği klasik yönetim anlayışı ile değil, asıl amacın hizmet etme olduğu, hedef ve stratejilerin benimsetildiği bir takım çalışmasıyla yakalanabilir. Çalışanlara nasıl yapılacağını söyleyip onları kontrol etme yerine, motivasyon ile sadece ne yapılacağını söyleyerek, takım elemanlarının yaratıcılıklarının ortaya koymaları sağlanabilir.

Yeni teknoloji, karmaşık iş yaşamı, küçülme, kalite, sürekli iyileştirme... son zamanlarda duyduğumuz günümüzün iş hayatında önemli kavramlardan sadece birkaçıdır. Aileden gelen genetik yetki, komuta kontrol sistemi ve bağımsızlık artık yok olmuş, sorumluluklar her alanda artarken, yetkiler aksine azalmaktadır. Değişim fırtınaları, iş yaşamını kasıp kavurmaktadır. Gelişmeler, etkisini lokal değil artık global olarak göstermektedir.

Tarıma ve el becerisine dayalı ekonomilerde ustalığın önemi, makineleşme ve sanayi çağı ile uzmanlığın öne çıkmasını sağlamıştır. Bacası olmayan, tüm sermayesi insanlardan oluşan işletmelerin olduğu bilgi çağında liderlik yaklaşımları önem kazanmıştır.

Klasik deyişle, değişmeyen tek şey değişimdir. Oysa değişime karşı bir direnç gösteririz. Değişim stres, çelişki ve uyuşmazlığı beraberinde getirir. Çelişkiler aslında problemleri çözmenin, yeni alternatifler üzerinde düşünmenin bir başlangıcıdır. Yeni dünya 
düzeninde kazananlar, değişimi dikkate alıp farkına varanlar arasından çıkacaktır.

\section{Toplam Kalite Yönetimi}

Toplam kalite yönetimi, bir kuruluştaki tüm faaliyetlerin sürekli olarak iyileştirilmesi ve organizasyondaki tüm çalışanların kesin aktif katılımı ile müşterilerin memnun edilerek karlıığa ulaşmasıdır. Toplam kalite yönetimi en düşük maliyetle en kaliteli çıktıyı arama çabasıdır. Toplam kalite yönetiminde çalışanların eğitimi, grup çalışması, katıım, her kademe yetki ve sorumlulukların paylaşımı vardır. Toplam kalite yönetimi felsefesi istatistiki düşünce sistemini baz almakta, verilerden üretilen bilgileri sistematik bir yapıda planlamadan başlayarak üretime kadar varan bir süreç içinde ölçme ve kıyaslamalarla değerlendirerek uygulamaya geçmektir. Kalite ve sürekli iyileştirmeyi amaçlayan sistem, üretimde yer alan bireylerin fonksiyon ve becerilerini değerlendirmek yerine organizasyonun verimini artırmayı hedef almaktadır. Bu yönetim şeklinde kalitenin ekstra bir maliyet yaratacağı inanışı, yerini kalite artışının daha ucuza mal edilebileceği inancına bırakmaktadır. (Ak ve Sartugan, 1996: 56)

Toplam kalite yönetimi dar anlamda "mal ve hizmet kalitesini" geniş anlamda ise kurum veya örgüt ya da organizasyon kalitesini sürekli olarak iyileştirmek için organizasyonda yapılması gereken tüm çabaları ifade etmektedir "Kalite Yönetimi" kelimelerinin başına "Toplam" kelimesinin eklenmesinin nedeni organizasyonel performansı ve verimliliği arttıracak tüm alanlarda kalite geliştirilmesinin amaçlanmasıdır.

Bugün literatürde "toplam kalite", "toplam kalite yönetimi", "toplam kalite kontrol" kavramları çoğu kez eş anlamlı olarak kullanılmaktadır. Toplam kalite yönetimi, müşteri odaklı bir sistem olup müşteri tatminini hedeflemektedir. Diğer bir ifade ile toplam kalite yönetimi, müşteri beklentilerini her şeyin üzerinde tutan ve müşteri tarafından tanımlanan kaliteyi, tüm faaliyetlerin yürütülmesi sırasında ürün ve hizmet bünyesinde oluşturan bir yönetim biçimidir. Dinamik pazarlarda, yıkıcı rekabetin karşısında ayakta kalabilmek ancak bu anlayışı benimsemekle mümkün olabilmektedir ( Erol, 1994:18 ).

Toplam kalite yönetimi, bir kuruluşta üretilen mal ve hizmetlerin işletme süreçlerinin ve personelinin sürekli iyileştirilmesi amacıyla, maliyetleri en düşük düzeyde tutularak önceden belirlenmiş hedef 
müşterinin, istek ve intiyaçlarını en iyi şekilde karşılamak için tüm çalışanların gönüllü katılımını sağlayan, işletme performansını geliştiren bir yönetim stratejisidir ( Peşkircioğlu, 1995: 27).

\section{Toplam Kalite Yönetiminde Liderlik}

Liderlikle ilgili yapılmış olan tanımlamalar liderliğin farklı yönlerini almıştır. Liderlik, bazen bir kişilik özelliği, belli bir makam ya da yetkinin niteliği, bazen de bir davranış türü olarak kullanılmıştır. Yapılmış olan bu ve bunun dışındaki tanımlamalardan çıkarabileceğimiz ortak bir nitelik, liderliğin bir etkileme gücü veya etkileme sanatı olmasıdır. Ayrıca liderlikle ilgili yapılan tanımlamalarda genellikle liderlikle lider arasında kesin bir ayrım yapılmamıştır. Oysa ki; lider bir bireyi, kişiyi simgelerken liderlik bir davranış biçimi olarak görülmektedir. Liderliği etkileme süreci olarak belirten bu tanımlarda lider bu süreci harekete geçiren birey olarak kabul edilmiştir.

Liderlik, görüşleri, eylemleri ve eğilimleri etkileme yönlendirme ve yönetmedir (Bennis ve Nanus, 1985: 56 ).

Liderlik, lider ile her bir izleyici arasında oluşan çift yönlü bir etkileşimdir (Grean, 1976: 227 ).

Liderlik güçlü bir etkidir ( Argyris, 1976: 227 ).

Liderlik, etkili kişisel özelliklere bağlı bir güçtür (Etzioni, 1964: 37).

Liderlik, izleyicilerin düşünce ve eylemlerini etkileme doğrultusunda güç kazanmadır (Zaleznik, 1997: 267).

Lider, kümesinin bir üyesi olarak, öteki üyeler üzerinde olumlu etkide bulunan kişidir. Başka bir değişle lider küme üyelerinin kendine yaptığı olumlu etkiden daha fazlasını onlara yapabilen küme üyesidir (Başaran, 1992: 53). Lider kavramı tanımlanmaya çalışılırken lider ile yönetici arasındaki farklılık belirlenmiştir. Yönetici politikayı sürdürmeye çalışır, lider ise politika belirler. Yönetici ağacı düşünür, liderin ise bakış açısı çok geniştir. Lider ormanla ilgilenir (Lunenburg ve Ornestein, 1991: 119).

Drucker'e göre etkili liderler sadece karar vermezler. Bu kişiler örgüte çok geniş bir açıdan bakar ve işgörenler üzerinde çok büyük bir etki oluştururlar. Liderler, günlük sorunları çözme ya da ortaya çıkarmadan çok, stratejik düşünceleri denerler. Yöneticiler, arzu edilen sonuca ulaşmak için örgütsel yapı ve süreci biçimlendirmeye çalışırlar. 
Oysa ki liderler, grubu bir vizyon etrafında birleştirmeye çalışırlar (Lunenburg ve Ornstein, 1991: 120).

Lider, grup üyelerince izlenen kişidir. Tüm yöneticiler lider değildir. Yöneticinin grup üyelerinin çoğunluğu tarafından benimsenmesi gerekmez. Lider ise grup üyelerinin tamamı veya çoğunluğu tarafından izlenen kişidir. Lider atamayla gelmediği için onun hiyerarşik yapı içinde belli bir konumu yoktur. İnformel liderler iş gruplarının lideridir. Ancak bunlar yönetici değildir.

Ödül Gücü; Liderler genellikle örgütteki ödül gücünden yararlanarak astlarının yeteneklerini değerlendirirler. Liderler işgörenlerin istediği ödülü kontrol ederler. Kime ne kadar ödül verileceğine liderler karar verir. Örneğin, ödül gücü ücret, yükseltme, değerlendirme ve övgü gibi güçleri kapsayabilir.

Zorlayıcı Güç: Bu güç ödül gücünün karşıtı olan güçtür. Zorlayıcı güç liderliğin direktiflerine karşı astların itaatsizlik göstermesi durumunda kontrol etme ve cezalandırma gücünü yansıtmaktadır. Örneğin zorlayıcı güçler; rütbe indirme, ücret artışını engelleme, davranışları cezalandırma gibi güçleri içermektedir.

Uzmanlık Gücü: Bu güç grubun intiyacını karşılamaya yönelik olarak liderin sahip olduğu özel yetenek ve bilgilerdir. Lider analiz etme, uygulayabilme ve kontrol etme yeteneğine sahiptir.

Karizmatik Güç: Karizmatik güç, liderin izleyenler üzerine sahip olduğu güçlü etkiye dayanır. Bu karizmaya dayalı güç liderin izleyenler üzerindeki çekiciliğini ve saygısını yansıtmaktadır.

Yasal, ödül gücü ve zorlayıcı güç, örgütsel gücü oluştururken uzmanlık gücü ve karizma gücü daha çok kişisel güçleri oluşturmaktadır. Karizmatik güç liderin kişiliğine ve kişilik yapısına dayanmaktadır.

Liderin güç kaynağına yönelik yapılan araştırma sonuçları (Lünenburg ve Ornstein, 1991: 122).

Yasal güç, işgörenler arasında sürekli olarak iş doyumsuzluğu, direnme ve çatışma oluşturmaktadır.Yasal güç, verimliliği olumsuz yönde etkileyebilir ve en düşük düzeyde itaat oluşturabilir. 
Ödül gücü, kısa bir süre için işgören performansını doğrudan etkileyebilir. Ödül gücünü uzun süre kullanma, işgörenler arasındaki duygusal ilişkileri ve iş doyumunu olumsuz yönde etkileyebilir. Zorlayıcı güç, korkuya dayanır. Bu kaynak fiziksel güç kullanmaktan, çalışanların işine son verme, yükseltmeme, sürgün etme gibi yöntemleri kapsar.

Zorlayıcı güç, işgörenler arasında geçici bir itaat oluşturabilir. Zorlayıcı gücün yan etkileri hayal kırıklığı, endişe, intikam alma ve yabancılaşma biçiminde ortaya çıkabilir. Zorlayıcı güç, iş doyumsuzluğu, düşük performans ve işgören devrine yol açabilir.

Uzmanlık gücü, güvene dayalı iklimle yakından ilgilidir. Liderin etkisi izleyenler tarafından işselleştirilir. Uzmanlık gücünü kullanan lider izleyenler arasında tutumsal bir bütünlük oluşturur ve güdülenmeyi içselleştirir.

Karizmatik gücü kullanan lider, izleyenler üzerinde coşkusal ve tartışmasız bir güven, bağlılık ve özdeşim oluşturmaktadır. Bu güç uzmanlık gücüne benzemekle birlikte uzmanlık gücünden daha az bir gözetim gerektirmektedir.

Başarılı bir lider bu güçleri kullanması ve uygulaması gereken kadarıyla uygulayabilen, zeki, dikkatli, eğitimli, bilgili, etkin, sosyal, uyumlu, popülaritesi yüksek, iletişim ve işbirliği kurabilen, yeterli, ilgili ve izleyicilerin gücünü daha iyi değerlendirerek daha çok güdüleyebilen liderdir.

\section{1. Vizyoner Liderlik}

Günümüz örgütlerinde meydana gelen yönetimsel, sosyal, siyasal ve teknolojik değişmeler ve gelişmeler, klasik yönetim anlayışının ve uygulamalarııı iki binli yılların çağdaş yönetim ilke ve gereksinimlerine cevap vermede yetersiz ve etkisiz kaldığının anlaşılmasına neden olmuştur. Klasik yönetim anlayışı ve anlayış içerisinde de alınan liderlik, tarihsel süreç içerisinde yerini yeni liderlik kuramlarına bırakmıştır. Bu süreçte liderlik konusunda özellikle iki binli yıllar liderlikle ilgili yeni yaklaşımların ortaya çıktığı bir dönem olmuştur. Öğretimsel liderlik, kültürel liderlik, dönüşümcü liderlik, vizyoner liderlik, liderlik alanındaki yeni yaklaşımları oluşturmuştur.

Vizyoner liderliğin önemi, örgütün geleceğe yönelik bir vizyon geliştirilmesinden ileri gelmektedir. Geçmişteki gelişmeler, açıkça 
belgelendirilemezse, bu durum örgütsel açıdan ciddi bir sorun oluşturur. Vizyoner lider, bu sorunu çözme başarısını gösterir (Schein, 1997, 16).

Vizyon, bir örgütün geleceğe yönelik resmidir. Bazen vizyon amaçla karıştırılmaktadır. Vizyon, arzulanan geleceğin resmidir. Amaç soyuttur. Vizyon ise somuttur (Senge, 1996: 165). Vizyon, somut bir gelecek görüntüsüdür. Gerçekleşmesini görebileceğimiz kadar yakın, ancak yeni bir yapılanmanın hayranlığını uyandıracak kadar da uzaktır. Vizyon gelecekte olabilecek ya da oluşturulabilecek bir durumun, bugün için düşünce düzeyinde oluşturulmasıdır (Heintel, 1995: 115).

Vizyon yokluğu örgütsel baş dönmesine yol açar ve örgütü körlüğe götürür. Her zaman vizyon oluşturma örgütsel başarı için zorunludur. Geleceğe yönelik bir bakış açısı olmadığı zaman her eğilimin önü tıkanır ve yok olur (Bennis, 1996: 53).

Vizyonlar işgörenlerin davranışlarını büyük ölçüde etkilemektedir. Bu etkiler şunlardır (Heintel, 1995: 115).

1. Duygusal uyarma ve çekicilik,

2. Ateşleme ve hayran bırakma,

3. İtici güç ve alışkanlıklar oluşturma,

4. Hatırlama yeteneğini geliştirme,

5. Yenilikçiliği destekleme,

6. Öncülük etme ve bütünleşme,

7. Yön gösterme ve aydınlatma.

Vizyon oluşturma oldukça karmaşık bir süreçtir. Vizyon, birden bire ortaya çıkan geleceğin görüntüsü değildir. Sezgi ve düşünce dünyasının geliştirilmesi, dünyaya yeni bir bakış açısının oluşmasını sağlar. Düşünsel ve sezgisel vizyonun bireysel düzeyden örgütsel düzeye çıkarılması her iki vizyonun paylaştırılması ile mümkün olabilir.

Yöneticiler, uzmanlar tarafından sunulan örgütün ekonomik, teknolojik, sosyal ve politik çevresinde meydana gelen olayları tanımak zorundadırlar. Çevresel yapının değişkenlik, yakınlık ve keskinlik gibi farklı özellikler taşıdığı görülmektedir. Vizyoner ve yeni bakış açısına sahip bir yönetici, diğer yöneticilerden farklı olarak değişik gelişmeleri ve olayları okuyabilme yeteneğine sahip olmalıdır.

Vizyoner lider, geleceğe yeni bir bakış açısıyla bakabilir ve bu yeni bakış açısını üstün bir yetenekle analiz ve sentez yapabilir. Vizyoner lider, vizyonu örgütün bütün kademelerine başarıyla iletebilir 
ve kurumsallaştırabilir. Bu lider sadece güce sahip değildir, düşünceleriyle, kendini izleyenleri etkileyebilir. Bir vizyonun örgütsel yaşamda kurumsallaşması, emirlerle ya da baskıyla gerçekleşmez. Vizyon daha açık ikna sözleşmesidir, işgörenler ve örgüt tarafından doğru algılanan ve zamanlanması doğru olan, işgörenlerde coşku ve bağlılık oluşturan bir sözleşmedir (Bennis, 1996: 60).

Vizyoner liderlik, insanları topluca etkileyebilecek ve harekete geçirebilecek vizyonları oluşturabilme ve iletebilme yeteneğidir. Yöneticilik ise yapılacak işleri algılama ve insanları çalıştırabilme gücüdür. İnsanlar diğer insanların değil, vizyonların peşinden giderler (Brengelmann, 1995: 26).

Vizyoner lider, sorunlara küresel ve sezgisel baktığı zaman kendini rahat hisseder, ya hep ya hiç biçiminde kökten karar almayı sever, kendini tamamen kendi buluşlarına yoğunlaştırır, kendine bağımlıdır. İletişimin yorumlanması gerçek liderlik sanatıyla ilgilidir. Vizyoner lider iyi bir iletişimcidir. Geçmişle gelecek arasında bağlantı kurar bilgileri seçer, organize eder ve geleceğe yönelik geçerli ve güvenilir bir vizyon oluşturur.

Kısaca vizyon; bir kurumun değerini, içinde bulunduğu durumu, ulaşmak istediği hedefleri belirleyen ve çalışanları ortak bir amaç etrafında bütünleştirerek kurumu arzulanan geleceğe doğru yönlendiren bir süreçtir.

\section{2. Kalite Liderliği}

TKY, müşteri memnuniyeti, takım çalışması, sürekli iyileştirme ve hata yapmama esaslarına dayalı çağdaş bir yönetim yaklaşımıdır. Bu yönetim yaklaşımı liderlik alanında "Toplam Kalite Liderliği” anlayışını ortaya çıkarmıştır. Toplam kalite liderliği, kalitenin arttırılmasında üst düzey yöneticilerin önemli sorumlulukları bulunduğunu kabul etmekle birlikte liderliği paylaşılmış bir süreç olarak görür. Kalite liderliği müşteri merkezli davranmaya yönelik bir liderlik biçimidir.

TKY' de üst yönetimin liderliği önemlidir. Sürekli gelişmeyi ve değişen hususlara ve müşteri beklentilerine etkili bir şekilde uyum sağlamayı ilke edinen toplam kalite yönetimi, bunu büyük oranda yöneticinin liderlik özelliklerine bağlamaktadır. Deming, TKY' nin örgütlerde üst yönetici tarafından başlatılması gerektiğine inanmaktadır. Deming'e göre "kalite yönetimdir" ve bir kurumun gelişmesindeki temel 
sorun üst yönetimin liderliğidir. Deming, Juran ve İshikawa gibi yazarlar üst yönetimin liderlik rolü üzerinde durmaktadır (Özden, 1999: 171).

Toplam kalite lideri sistemden ve insandan sorumludur. Juran, bir örgütün başarısını sistem ve insan olarak iki önemli faktörün belirlediğini savunur. Bu iki faktörün sonuç üzerindeki etkisini de \% 85 sistem, \%15 insan şeklinde ifade eder. Sistemin tasarımı ve işletilmesi doğrudan üst yönetimin sorumluluğunda olan bir alandır. İnsanı yönetme sorumluluğu da kalite liderinin sorumluluk alanı içindedir.

Toplam kalite liderliği sürekli gelişmeyi hedefler. Sürekli gelişme kalite yolculuğunun yaşam boyu devam etmesidir. Başka bir ifade ile sürekli gelişme öğrenen örgütün kaliteyi sürdürme konusundaki kararlı davranışıdır (Çelik, 2000: 187). Değişime uyum sağlamayan örgüt ölür. Toplam kalite yönetimi felsefesinde "Yeterince iyi iyi değildir" ilkesi vardır. Rekabet ve vatandaş veya müşteri beklentilerinin sürekli olarak değişmesi üretilen ürün ya da hizmetin kalitesinin geliştirilmesini zorunlu kılar.

Kalitenin sağlanması ve sistemi iyileştirme görevinin üst yönetimde olduğuna inanan Deming, yöneticinin kalite liderliği açısından şu liderlik özellikleri üzerinde durmaktadır (Özden, 1999: 71).

-Güven ve yardım sağlar fakat yargılamaz

-Tüm çalışanlara kendilerini geliştirme fırsatı verir.

-̇̇şgörenlere, içinde çalışmaktan onur duyacakları iş ortamları sağlar

-Çalışanların işlerinden zevk almaları ve performanslarını en üst düzeye çıkarmaları için çaba sarf eder.

Kalitenin sağlanmasında üst yönetimin kritik bir rol üstlenmesi TKY sisteminin oluşturulmasında kalite liderliğinin önemini arttırmaktadır. Toplam kalite lideri, toplam kalite felsefesinin benimsetilmesine çalışır. Örgütsel güvene dayalı bir ilişki sistemi oluşturur. Kalite lideri, kalite ilke ve uygulamaları hakkında sürekli eğitim sağlamak için gerekli kaynakları kullanır. Toplam kalite liderliği, korku değil, güven üzerine kurulur.

Toplam kalite liderliğinin önemli bir boyutu müşteri tatminidir. Toplam kalite lideri müşteri odaklı düşünen liderdir. Müşteri / vatandaş kendi isteklerini gerçekleştirmeye yardımcı olan ve bu amaca hizmet eden politikaları benimsemiş örgütleri benimserler. 
Hata yapmama, sürekli gelişme ve vatandaş tatmini gibi belli ilkeler üzerine kurulan kalite liderliği bir yaşam felsefesine dönüşmedikçe, belli sözlerden oluşan bir slogan olmaktan öteye geçemez. Kalite liderliği, yaşam kalitesinin yükseltilmesine katkı sağlamalıdır. Başlangıçta kişisel yaşam kalitesinin yükseltilmesi ve daha sonra kurum örgütsel kalitesinin yükseltilmesi gerekir. Toplam kalite liderliği davranışın somut olarak algılanmasını gerektirir.

Kalite geliştirme programı karizmatik olmakla birlikte, kitleleri peşinden sürüklemesini bilen, saygıdan çok eylem ilham eden, güçlü olmamakla beraber yetkilendirme alışkanlığı olan bir lider gerektirir.

Başarıı bir liderde olması gereken nitelikleri özgüven, kararlıık, cesaret, olumlu düşünme, sorumluluk, öğrenme arzusu, insiyatif, yaratııılık, iletişim yeteneği, karizma, empati, ikna gücü, güvenilirlik olarak belirtebiliriz.

Başarılı liderliğin kurallarını ise; amaç ve hedef belirlemek, geleceği planlamak, misyon belirlemek ve vizyon oluşturmak, ekip kurmak ve yönetmek, sorun çözücü olmak, etkin kararlar vermek, yetki devretmek, motive etmek, başarılı iletişim kurmak, zamanı iyi yönetmek, başarılı müzakereler yapmak, çatışmaları çözmek, değişimi yönetmek, performans değerlendirmek, stresi yararlı kılmaktır.

TKY, liderlikte kalite, kalitede liderlik önermektedir. Bu da üst yönetimden başlayarak tüm yönetim kademesinin bilgi, beceri, katılım, iş ahlakı, yaşam tarzı gibi her konuda örnek davranışlarda bulunulması demektir. Kamu yönetiminde en büyük sorunlardan birisi yöneticilerin lider olma gayreti içinde bulunmamalarıdır. Yeni atanmış otoriter kolaycııığını bırakıp benimsenmiş yönetici pozisyonuna geçmek için çaba göstermemeleri (Efelerli; Gerek; Akgün, 1998: 153). "Balık baştan kokar." Sözünü haklı ve geçerli kılmaktadır.

Günümüzde yönetim tanımı da değişmiştir. Artık yönetim, mevcut sistemleri sürekli geliştirerek, çalışanların katıımını sağlayarak, daha yüksek kalite, verimlilik düzeylerini yakalamak ve sürekli bu düzeyleri aşma yolunda astlara liderlik yaparak onları değişime, kaliteye ve katıııma güdülemek, örgütü kar maksimizasyonunda yöneltmek ve tüm bu amaçlara ulaşabilmek için önce kendinden başlamak üzere tüm 
örgütte radikal değişimleri başarmaktır. Değişim yönetimini yaşama geçirebilmek ve katılımcılığı sağlayabilmek önce yönetim tanımının yeniden yapılmasını gerektirmektedir.

Katılımcı ve kalite anlayışına dayalı yönetimde başarılı olabilmek için örgütsel iletişim sistemi tek yönlü bir yapıdan çok yönlü bir yapıya kavuşturulmalıdır. Örgüt içinde bilgi içerikli iletişim ağının kurulması ve tüm çalışanların bu bilgi iletişiminde aktif olarak yer alması önemli katkılar sağlayacaktır. Sorunların çözümüne, süreçlerin geliştirilmesine yönelik katılıma motive olmuş çalışanların bireysel ve grupsal etkinliklerinin başarılı olabilmesi bu çok yönlü bilgi içerikli iletişim sisteminin varlığına bağlıdır.

Liderlik, bir organizasyonun kalbidir, ruhudur. Hiç kimse organizasyon planlarını yeniden değiştirmek, sayıların yerini değiştirmek suretiyle bir organizasyonu gerçek manada kuramaz. Liderlik, hedefi başarmak için takım olarak birlikte çalışma, insanları bir araya toplayabilme sanatıdır. İnsanoğlu etkili bir lideri takip etmek ister.

Hiçbir lider kurumunun başarısında liderliğin en alt kademedekilere ne kadar katkıda bulunduğunu kanıtlayamayız. Ancak liderlik, kurumun şüphesiz en önemli unsurlarından biridir. İnsanları bir araya getiren iyi liderlik organizasyon başarısına \%80 veya \%90 katkıda bulunur. Böyle bir liderlik iyi bir iletişim ile kazanılabilir.

Liderler kendilerini iyi ifade edebilen kişilerdir. Ne istediklerini, istedikleri şeyi neden istediklerini diğer insanların desteğini alabilmek için ne şekilde iletişim kurulması gerektiğini bilen insanlardır. Liderlik yönetimin en önemli bölümüdür.

Liderlik insanları heyecana getirme, canlandırma sanatıdır. İnsanın ufkunu açan, onları coşturan, yeni hedefler belirleme olgusudur. Bireysel örnekler belirleyen işlerde coşkunluk yaratan çalışanlarla hem konuşma yoluyla hem de onları dinleyerek kendileriyle iletişim kurabilme sanatıdır. Liderlik değere layık olanı dürüstçe ödüllendirme, kusuru da aynı şekilde cezalandırmadır. Liderlik insanın içinden gelerek yapılan işin daha çok başarılı olmasını sağlamak için doğru olan değerler kombinezonudur. Liderler otorite ile liderlik arasındaki farkı anlamalıdırlar. Otorite yukarıda bahsedilen emir zincirindeki yetkiden gelir, oysa liderlik asaletten kazanılır. 
Her şeyden önce liderlik bir hizmet görevidir. Liderler bir organizasyonda çalışanların önemli ve değerli elemanlar olduğunun bilincindedirler. Bu anlamda çalışanların bir şeyler başardıkları hissini vermek için alışanların aleyhine değil lehine çalışmalıdırlar.

Tarihin başlangıcından buyana, insanlar liderliğe olan ilgiyi ve merakı araştırmaya çalışmaktadırlar. En iyi yaklaşımın çevre, kültür ile belli başlı bazı kavramlara göre değişik gösterdiği sonucuna varmışlardır.

Organizasyonel iletişim belli bir ölçüye kadar emir ve talimatlar vermesine kadar insanlar liderliği yönetilenlere verilen görevleri yerine getirmeye zorlama şeklinde algılamaktadırlar. Günümüzde başarılı yöneticiler çalışanlarını zorla değil onları etkileyerek, ikna ederek görevlerini yerine getirmektedirler. Kaliteli iletişim liderlerin vizyonlarının anlattıkları organizasyonda katılımcı yönetim anlayışı ile görüşlerini ifade ettiği yönetimsel yönünün geliştirdiği bir yoldur.

Liderliği tanımlayan yaklaşımları şu şekilde sıralayabiliriz

1. Kişisel özellik yaklaşımı,

2. Üslup yaklaşımı,

3. Etkinlik ve yeteneğin karşılaştırması yaklaşımı,

4. Güç yaklaşımı,

5. Fonksiyon yaklaşımı,

6. Yetenek ve yeterlik yaklaşımı,

7. Toplam kalite yönetimi yaklaşımı.

Kişisel özellik yaklaşımına göre liderler, lider olarak doğarlar. Bu anlamda bazı insanların kişisel özellikleri ve karizmalarından ötürü lider kabul edilirler ve diğer insanlarda onların bu özelliklerinden dolayı lider kabul ederler. Karizmatik özelliklere sahip olan insanlar liderliği bilinçli bir şekilde kullanma ve geliştirme sanatını öğrenmelidirler.

Üslup yaklaşımı, birkaç noktayı kapsayan zorbalıktan demokratik bir yapıya uzanan

bir liderlik stilinin kullanımını ifade eder. Zorba lider karar alır,ve bu kararı yönetilene bildirir. Demokrat lider ise kararları gurupça alır. Bu iki farklı uç arasında yetkinin derecesine bağlı olarak değişen farklı anlamda liderlik şekilleri bulunabilir. Aslında bütün liderler değişen şartlar altında farklı tarzlar kullanırlar. Bunlardan biride çok sıkça kullanılan "egemen" olmadır. 
Nelda Spinks ve Barron Wells insanların, davranışları, inançları, duyguları ve görüşleri değişmezken, dışarıya yönelik tavırlarının değiştirdiklerini belirtir. Davranışlarda küçük değişikliklerin meydana gelmesi, iç dünyasında değişimlerin ortaya çıkmasına işarettir. Bundan dolayı davranışları, duyguları ve görüşleri liderinkiyle paraleldir. Davranışlarda küçük değişimlerin gerçekleşmesi olgusu kalıcı değişimlere tesir etmek isterken davranış tarzı değişimlerden daha önemlidir.

Kalite liderliği organizasyonlarda etki sonucunu alır. Liderlerin ne ilettiği etkisi belki de ne dedikleri ya da yaptıklarından daha baskındır. Liderlerin, amaçlarını gerçekleştirmek uğruna günümüzün gelişmiş organizasyonlarında insanların kapasitelerini zorlayacak, üzerlerinde tamamen hakimiyeti kuracak, onları denetleyen konumuna geçtikleri fazla görülmez. Aksine liderler, çalışmaların başarılı olmasına ve amacın gerçekleşmesinde katkısı olan düşünce üzerindeki etkiyi denetlerler. $\mathrm{Bu}$ etki, liderler tarafından sadece kaliteli iletişim uygulanarak gerçekleştirilebilir.

Motive edebilme yeteneği liderlerde öncelikle aranan bir niteliktir. Motivasyon insan davranışları hakkında algılama, davranış, kişilik gibi davranış tarzını oluşturan parçaları anlama yeteneği gerektirir. Motivasyon, insanların belli gereksinimlerinin karşılanmasını sağlayacak tutumların sergilemek için bireyleri etkilemek ya da ikna etmekten oluşan bir süreçtir.

Kalite liderliği, çalışanları organizasyonu faydalı bir şekilde çalışmalarını sağlama sebeplerini içerir. Kalite üretiminin gerçekleşmesini, çalışanlarını motive etme yoluyla sağlamak için, onların fikirlerini de alarak uygun amaçlar belirlenmelidir. Amaç belirlenmemişse ya da çalışanların amaç saptama konusunda herhangi bir katkıda bulunmuyorlarsa, onlar verilen görevi başarıyla yerine getirecek kadar motive edilmemiştirler. 


\section{SONUÇ}

Liderler ve çalışanlar arasında karşılıklı güven olması kalite performansı için çok önemlidir. Güven olmadığı yerde motivasyon amaçlı girişimlerden bir çoğu başarılı olamazlar. Yapıcı eleştiri uygulayan liderler, ilk önce ekip çalışması yoluyla çalışanların saygısını ve kabulünü kazanmalıdır. Liderleri lider yapan olgu, insanların güvenini kazanma yetisidir. Güven, sürekli ve güvenilir olan kalite iletişimi yoluyla elde edilir. Güven, liderleri ve takipçilerini birleştiren bir unsurdur. Kalite iletişimi güvenin habercisidir.

Dinleme yeteneği, motivasyonel süreçte kullanılan bir kalite iletişim aracıdır. Dinleyen bir lider gelişen bir iletişime yön verir. Şeffaf bir politika, iletişimi nasıl geliştiriyorsa iletişim de ekip çalışmasını gerçekleştirir, üretkenliği sağlar.

Organizasyonlarda ürün ve hizmet kalitelerini artırmak ve ilerleme yönündeki çabalar süreklilik göstermemektedir. Organizasyonlar, (iç ve intra organizasyonel olarak) ilişkilerde kalite geliştirmek için uğraşırlarsa, global bir ekonomide yerlerini daha da sağlamlaştırırlar.

Sonuç olarak liderin sahip olması gereken özellikleri temel başlıklar altında toplamak gerekirse Lider;

Dürüst, gerçekçi, zeki ve pratik olmalıdır. En zor koşullarda çare bulucu, zor problemi çözen kişi olmalıdır. Kendini büyük, insanları küçük gören kişi olmamalıdır. Çalışanı ve çalışmayanı ayırt edebilmeli, takdir ve cezayı yerinde kullanmalı, çalışanın düşüncelerini dinlemeli, çıkan karar müşterek karar olmalıdır.

Lider, hep emir veren insan değildir. Mahiyetinde çalışan insanların veya ünitelerin tekliflerini dikkate almalı, tekliflere açık olmalıdır. Ve her ünite kendileri ile ilgili olarak, ünitenin daha verimli çalışması için teklifler sunmalıdır. Lider, mütevazi ve gölgede kalmasını bilen kişidir. Paylaşımcı ve eğitici olmalıdır. 


\section{KAYNAKÇA}

AK, Bilal; SARGUTAN, Ertan (1996) "Hastanelerde Toplam Kalite Yönetimi ve Uygulama Örnekleri" Standart Dergisi, Yıl:35, Sayı:414, , s.56-6 ARGYRIS, C (1976) Increasing Leadership Effectivenees, New York: Wiley BENNIS, W, NANUS, B (1985) Leaders: The Strategies For Taking Chance, New York: Harper and Row

BRENGELMAN, J (1995) Vizyon Yönetimi, (Çev:Veli KARAGÖZ), Evrim Yayınevi, İstanbul.

ÇELiK, Vehbi (2000) Eğitimsel Liderlik, Pegem Yayıoncılık, Ankara

EFELERLI, Saim; GEREK Cüneyt; AKGÜN İbrahim (1988) "Kamu Yönetiminde Toplam Kalite Yönetimi” Kamu Yönetiminde 1. Kalite Kongresi, TODAIE Yayını, s.151-156

EROL, Zeki (1994) "Kriz ve Kalite” Önce Kalite Dergisi, Yıl:3, Sayı:9, s.237245

ETZIONI, A (1964) Modern Organizations, New Jersey: Prentice-Hall.

GREAN, G.B (1976) "Role-Making Process Within Complex Organizational Psycholopy" Chicago: Rand McNally, s.4-8

HEINTEL, P (1995)Vizyon ve Öz Yapılanma Vizyon Yönetimi (Çev: Veli KARAGÖZ Evrim Yayınevi, Istanbul.

http://www.merih.net/m2/rsc/wcevaca01.htm

http://www.swordtechnology.com/billgates.htm

http://www.la21turkey.net/dl/yg21gp0903_iletisim_ve_liderlik..Ebru Özgen thtp://www.ba.metu.edu.tr/ manclub/yayinlar/glokal/sayi10/liderlik1.htm http://www.danismend.com/konular/insankaynaklari/LIDERLIK\%20SENFONISI. $h$ tm 
http://www.kho.edu.tr/yayinlar/bilimdergisi/bilimder/doc/2001-2/1-bilder.doc

http://www.spk-mpd.org/mdogu05.doc

LUWENBURG, F.C; ORNSTEIN, A.C (1991) Educational Administration, Belm Wodsworth Publishing Company.

MAXWELL John C. (1998) I Çcinizdeki Lideri Geliştirmek, Beyaz Yayınları, Istanbul

ÖZDEN, Y (1999) Eğitimde Dönüşüm, Pegem Yayınları, Ankara.

SCHEIN, E (1997) Organizational Culture and Leadership, San Francisko: JosseyBass.

YATKIN, Ahmet (2003) Toplam Kalite Yönetimi, Nobel Yayıncılık, Ankara YATKIN, Ahmet (2003) Halkla Iilişkiler ve İletişim, Nobel Yayınları, Ankara ZALEZNIK, A (1997) Managers and Leaders: Are They Different? Harward Business Rewiew, Vol 55. 